\title{
Introduction: Islamic reformism in South Asia ${ }^{1}$
}

\section{FILIPPO OSELLA* and GAROLINE OSELLA ${ }^{\dagger}$}

\author{
*Department of Anthropology, University of Sussex, Brighton, \\ BNI 9SJ, United Kingdom \\ E-mail: F.Osella@sussex.ac.uk \\ ${ }^{\dagger}$ Department of Anthropology and Sociology, School of Oriental and African \\ Studies, Thornhaugh Street, Russell Square, London, \\ WCIH OXG, United Kingdom \\ E-mail:CO6@soas.ac.uk
}

\section{Introduction}

The authors in this volume discuss contemporary Islamic reformism in South Asia in some of its diverse historical orientations and geographical expressions, bringing us contemporary ethnographic perspectives against which to test claims about processes of reform and about trends such as 'Islamism' and 'global Islam'. The very use of terminology and categories is itself fraught with the dangers of bringing together what is actually substantially different under the same banner. While our authors have often found it necessary, perhaps for the sake of comparison or to help orient readers, to take on terms such as 'reformist' or 'Islamist', they are not using these as terms which imply identity-or even connection-between the groups so named, nor are they reifying such categories. In using such terms as shorthand to help identify specific projects, we are following broad definitions here in which 'Islamic modernism' refers to projects of change aiming to re-order Muslims' lifeworlds and institutional structures in dialogue with those produced under Western modernity; 'reformism' refers to projects whose specific focus is the bringing into line of religious beliefs and practices with the core foundations of

\footnotetext{
${ }^{1}$ We thank Edward Simpson, Benjamin Soares, Leila Zaki, John Mitchell, Kostas Retsikas, Magnus Marsden, Atreyee Sen, Simon Coleman, Irfan Ahmad and Francis Robinson for commenting on this Introduction. Responsibility for the ideas expressed herein remains ours alone.
}

oo26-749X/07/\$7.50+\$0.10 
Islam, by avoiding and purging out innovation, accretion and the intrusion of 'local custom'; and where 'Islamism' is a stronger position, which insists upon Islam as the heart of all institutions, practice and subjectivity-a privileging of Islam as the frame of reference by which to negotiate every issue of life; 'orthodoxy' is used according to its specific meaning in contexts in which individual authors work; the term may in some ethnographic locales refer to the orthodoxy of Islamist reform, while in others it is used to disparage those who do not heed the call for renewal and reform. 'Reformism' is particularly troublesome as a term, in that it covers broad trends stretching back at least 100 years, and encompassing a variety of positions which lay more or less stress upon specific aspects of processes of renewal; still, it is useful as a term in helping us to insist upon recognition of the differences between such projects and such contemporary obsessions as 'political Islam', 'Islamic fundamentalism' and so on. Authors here are generally following local usage in the ways in which they describe the movements discussed (thus, Kerala's Mujahid movement claims itself as part of a broader Islahi-renewal-trend and is identified here as 'reformist'). ${ }^{2}$ But while broad terms are used, what the papers are actually involved in doing is addressing the issues of how specific groups deal with particular concerns. Thus, not, 'What do reformists think about secular education?', but, 'What do Kerala's Mujahids in the 20oos think? How has this shifted from the position taken in the 1940s? How does it differ from the contemporary position of opposing groups? And how is it informed by the wider socio-political climate of Kerala?' The papers here powerfully demonstrate the historical and geographical specificity of reform projects, whereas discourse structured through popular mainstream perspectives (such as 'clash of civilizations') ignores such embeddedness.

The articles are written at a time when employees of Euro-American state agencies appear at academic conferences whenever 'Islam' or 'Muslims' are discussed and when academics themselves are being asked to contribute directly to the so-called war on terror, for instance by spying on their Muslim students or by embedding an explicit critique of radicalism into Islamic Studies degree programmes. Academics have been called upon to produce research which would help governments and security agencies to discern 'good Muslims' from 'bad Muslims' and research funding has been diverted towards

\footnotetext{
${ }^{2}$ We do not find any of our authors here discussing Islamism in terms of salafism; while individual papers discuss the deeply problematic term wah'habism.
} 
this, as in a recent research programme co-sponsored by the British Foreign \& Commonwealth Office and ESRC UK (see Houtman 2006; Keenan 2006, 2007; cf. Mamdani 2004). What we notice of these programmes is that they generally entail a malicious refusal to acknowledge the role of Western governments' aggressive foreign policy in producing the very thing these governments most fear. This is part of a wider reluctance to address an issue which is animating debates among Muslims in South Asia and beyond: the role of western 'neo-colonialism' or 'neo-imperialism' (in the terms commonly used by Indian Muslims) in what appears to many as a deliberate-and overtly Islamophobic — attempt to undermine Muslim religion, society and culture.

In such calls for research, reformism, Islamism and radicalism are pulled together and presented as though generated exclusively from within Islam itself, perhaps as an inevitable expression of a religious tradition which is essentially inimical-and militantly opposed-to modernity (see e.g. Giddens 1999: 4-5). But not all Muslims are charged with being non-modern, conservative or opposed to 'the West' in the same way: the discourse framing calls for research presents us with a scenario in which we can (and must) identify 'good' and 'bad' Muslims. It is here that we discern an unfortunate overlap between anti-terror rhetorics and a long tradition of sociological research on Islam.

In South Asia as elsewhere (see e.g. Otayek and Soares 2007) much ethnographic work celebrates sufi-inspired forms of Islam as tolerant, plural, authentic and so on, against a maligned Other of reformist Islam. The latter is often regarded as a threat to what are argued to be culturally specific forms of South Asian popular Islam (see eg. Ahmad 1981 and the following debate between Robinson 1983, 1986, Minault 1984 and Das 1984; see also Roy 2005). Reform is understood to embody practices which are either alien to the majority of South Asian Muslims, or altogether external to South Asian traditions (see e.g. Gaborieu 1989 ${ }^{3}$ ). Islamic reformism here appears almost as a mirror image of Hindu fundamentalism: polarizing identities and disrupting inclusiveness and religious toleration, but, unlike its Hindu counterpart, sinisterly not home-grown. It is of little surprise, then, if anthropologists and sociologists have paid little attention to the complex relationships and debates between 'reformists' and

\footnotetext{
${ }^{3}$ Cf. debates, following Geertz (1960), between Hefner (1985), Woodward (1988), Bowen (1989), Beatty (1996) and Howell (2001) on Indonesian 'syncretism'.
} 
'traditionalists' (for notable exceptions see Van der Veer 1992; Hansen 1999; Gardner 1985; Ewing 1997; Simpson 2006; Marsden 2005; Blank 2001; Verkaaik 2004). Instead they have concentrated mostly on the study of popular religious practices-in particular, sufism and saints' shrine worship (Roy 2005; see e.g. essays in edited collections by Ahmad 1981; Troll 1989; Werbner and Basu 1998; Waseem 2003; Ahmad and Reilfeld 2004; see also Bayly 1992; Ewing 1997; Werbner 2003). A recurrent theme in these studies is a putative opposition between sufism's syncretism or hybridity (cf. Assayag 2004; Van der Veer 1994 for attempts to move beyond syncretism), or what is more generally claimed as sufism's cultural sensitivity and pluralism (Werbner 2003; cf. Ewing 1997; Mayaram 1997) positioned against what are characterized as the essentialist and purifying logics of Islamic reformism.

This opposition between (good, authentic) sufi-inspired popular practices and (bad, inauthentic) reformism is extremely unhelpfulif not altogether wrong-on a number of counts. ${ }^{4}$ Firstly, it naïvely suggests a tension between 'little' (read popular) and 'great' (read ashraf or scriptural) traditions-a theory long discredited with reference to Hinduism (see e.g. Fuller 1992: 24-28) and Christianity (see e.g. Stewart 1991). Such a dichotomy does not bear relation to South Asian Muslims'- 'traditionalists' and 'reformists' alike—close appeals to scriptural traditions to guide practice. Secondly, it assumes 'reformism' and 'traditionalism' to be substantial categories, rather than being produced discursively-and rhetorically-in the context of public debates (Asad 1986; Soares 2005; Eickelman and Piscatori 1996; Eickelman and Salvatore 2004). Of course, in public debate between groups, Muslims themselves use such antinomian labelling as a political tool. But in practice we find-unsurprisingly-categoryblurring orientations such as 'sufi' reformism (Green 2005), but also 'reformist' traditionalism, as in Deoband's early support of some sufi practices (Metcalf 1982; cf. Kresse 2007). The papers here also confirm that ideological positions are negotiated by and between ulema (religious scholars) and ordinary Muslims alike and are constantly subject to modifications. Most helpful to keep in mind is the idea of Islam as a discursive tradition (Asad 1986; Zaman 2002). Thirdly,

\footnotetext{
${ }^{4}$ While the 'bad' Muslims (Islamists) are the same across the academic and state configurations, the 'good' Muslim in the sociological record-the sufi-inspired follower of 'syncretic' practice and local 'custom'-is quite different from what would be the 'good' Muslim for Western governments. We will return to this point.
} 
it insists on the particularism of certain practices which, in fact, are not at all particular to South Asian 'popular' Islam but are found in many Muslim societies (see e.g. Manger 1998; Otayek and Soares 2007). Fourthly, it attributes such practices with fluidity, negotiation and openness, while reformism is characterized as closed, rigid and dogmatic. Several papers in this collection show how reformismwith its stress on ijtihad (independent reasoning) and reasoned, fresh, interpretation and debate-tends to open up rather than close down debate and can sometimes produce new and unexpected possibilities of interpretation.

Finally, academic upholding of an ideologically weighted opposition between 'syncretic sufism' and 'reformism' plays into the hands of those political forces who argue that reformism is a recent and external addition to South Asian Islam which needs to be purged back out or denounced as false consciousness. Here, a worrying tendency is the way in which substantially different traditions of reformism are all lumped together into one reified category which is then inaccurately shorthanded as 'wah'habism 5 and branded as extremist if not altogether demonized as terrorist. ${ }^{6}$ In the Indian context, we are faced on the one hand with the alleged foreignness of reformism; and on the other, with reformist insistence on the purification of un-Islamic elements (innovations/local adaptations) from practice. This leaves contemporary Indian Muslims, who cannot but be aware of reformist discourse, in an impossible double-bind: faced with a choice between being charged as 'bad Muslims' if they ignore the call to reform or as 'bad Indians' if they choose to follow reform. Mis-characterizations of popular Islam as essentially localized and containing hangovers from pre-conversion eras also allow Hindu revivalist organizations to argue that, deep down, popular Islam contains strong Hindu elements and that, hence, Indian Muslims can (and should) eventually be won back to Hinduism.

The ethnographic articles in this volume move away from facileand obviously dangerous - generalizations, opting instead to build up on a historiography of South Asian Islam which has explored sensitively

${ }^{5}$ This move is, of course, not new: as early as 1857 , Muslims accused of being the ringleaders of insurgency were routinely branded by colonial power as dangerous 'wah'habis' (Robinson 1993; Hermansen 2000; Ansari 2005).

${ }^{6}$ See Faisal Devji's critique of attempts to draw connections between Islamism, 'wah'habism' and terrorism (2005), and G. P. Makris' discussion of how terminology tends to be either 'emotionally loaded' or 'based on questionable socio-political assumptions' (2007: 193). 
and extensively the emergence of various strands of reformism in the context of the specific political and religious circumstances of nineteenth-century British India. However, while historians have focused on formal or organized Islamic reform movements (see e.g. Metcalf 1982; Troll 1978; Robinson 2001; Sikand 2002; Sanyal 1996), less attention has been paid either to regional or informal Islamic reformism (see e.g. Simpson 2006 for coastal Gujarat; Miller 1992 for Kerala) or to popular responses to the activities and appeals of the reformist ulema (cf. Mayaram 1997; Minault 1998). The volume as a whole works to show how debates between 'reformist' and 'traditionalist' Muslims produce shifts in practice and work to redefine the focus of 'reform' and 'anti-reform' alike, while reminding us that, even if Muslims themselves work with a sharp binary between 'orthodoxy' and 'reform', this opposition is a political device and practice is always far more complex, as people reason, negotiate, compromise and shift over time.

Contributors to this volume are also in critical engagement with recent studies which, by stressing the uniqueness of Muslim experience over-privilege the coherence and disciplinary power of contemporary piety movements (in particular, Mahmood 2004; Hirschkind 2006; but see also Brenner 1996; Deeb 2006; Henkel 2007). Magnus Marsden explores ways in which outspoken Chitrali women use their eloquence-in a context where positive value is attributed to plain speaking-to challenge both reformist and traditionalist orthodoxy. Marsden draws our attention to both the scepticism and disenchantment of some with the region's Islamicization and the ways in which the 'men of piety' find themselves moderating their self-presentation. Maimuna Huq considers the tension amongst Bangladeshi Jama'at-I-Islam university-going women activists between a simple reproduction versus a creative interpretation of the organization's own vision of Islam. In both Marsden and Huq's papers, as also amongst the Muslim feminists discussed by Vatuk, ijtihad - promoted in reformist discourse-fosters critical stances. Edward Simpson and Rubina Jasani, writing about very different Indian Gujarati Muslim communities, both stress the complexity, pragmatic and contingent nature of people's engagement with (reformist and not) Islam. While Jasani describes pragmatism and scepticism, Simpson offers us a study of the same three men over ten years, which clearly shows the shifts in their opinions and practices and the ways in which other factors impinge upon the latter. This leads Simpson to warn against privileging religion as the 
principal—or perhaps unique—foundation for Muslim identity and practice.

Muslim/Islamic exceptionalism is also contested in Francis Robinson's contribution, where he reminds us that South Asian Muslims' reformism-in all its forms-expresses a historically specific engagement with modernity. Robinson reminds us that reform is not recent, having roots in the deep Islamic past and already existing in formalized form in the eighteenth century. Nile Green and the Osellas consider the wider modern context which underpins the emergence and development of reformism. Green is concerned with tracing the import of colonial shifts towards a novel discourse on breathing, meditation and the body. 'Reform' produced the Yogi and the Sufi both as authentic indigenes and as representatives of newly communalized communities. The Osellas discuss the rich trajectories of Kerala's reformism, which encompass a history of links to the Arab world; 1920s' and 1930s' agitations to break with the nineteenthcentury colonial past; Kerala's famed 1950s' post-independence social activism; and a pan-Indian post-1980s' religious revivalism. As these papers make clear, reform and the production of Muslim identities alike clearly emerge as deeply embedded in local histories and political formations, in critical tension with Islamic reformism's universalistic orientation.

There is also always potentially a multiple audience for any debate: the self, which is the object of reform; the 'unreformed' Muslim; alternative styles of reformism (e.g. Tablighi versus Jama'at-I-Islami); the non-Muslim other; those in power (e.g. the state, potential funders, imperial power). Many papers explore the fact that while an imagined 'global Islam' may act as one referent for specific projects of reform, actual lived relationships with other local communities are equally salient. Arshad Alam discusses the narrow orientation of two north Indian madrasas, concerned primarily to train students in reproducing sectarian differences between Barelwis and Deobandis. Non-Muslims are here presented as peripheral-even irrelevant-to reformists' concerns. Farzana Haniffa makes her focus the relations between non-Muslims and reformist Muslims. Here, as in India, Muslim experience of being consistently marginalized as an alien Other (cf. Hansen 2007) can accelerate reformists' urges to draw close to the imagined community of the global umma. Such processes of repudiation, abjection and attempts at recuperation may have unintended political consequences. Haniffa explores how processes of crafting the self-consciously pious Muslim female subject are working 
to recast the ethnic identity of 'Muslim' in a manner which produces it as exclusive of ethnic others.

If reformism is not a disembedded universal, nor is it endowed with the unfettered agency so evidently dreaded by its many critical commentators. Elora Shehabuddin discusses the interesting process by which one of the apparently most ideologically robust of reformist organizations - the Jama'at-I-Islami-in practice makes compromises, shifts position and offers pragmatic concessions which take it away from its own avowed policy fundamentals (all this, too, in the Muslim majority nation of Bangladesh). Irfan Ahmad also studies Jama'at-I-Islami (here in India) and shows us how the founder Maududi's original thoughts on women are not unequivocally antifeminist. While Maududi is, Ahmad argues, 'neopatriarchal', he also, for the first time, considers women as individuals and opens up Islamist activism to them. This paves a pathway for later Jama'at activists to make some radical ideological moves and for the movement as a whole to shift position on 'women's issues' over time. Ahmad argues strongly that Islam has no essence, hence a non-patriarchal reading of Islam is plausible, and adds that to impose a blanket label of 'right-wing' on all Islamist movements is misleading.

The Jefferys reiterate the claim that we cannot assume slavish conservatism among ulema or followers, focussing on one issue which has been the subject of enormous anti-Muslim polemics: contraception. They argue that 'Islamic doctrine' and clerical pronouncements alone provide a poor basis for interpreting Muslims' fertility behaviour in contemporary India, while showing that the ulema do not propose rigid or unchanging demands on Muslims, but negotiate and shift position in their practices of reasoned interpretation. Indeed, reformist ulema pronouncements may sometimes urge ordinary Muslims themselves to be less uncompromising. Sylvia Vatuk returns us to a focus on that emerging phenomenon of 'a new breed of Muslim women scholar activists' who are, she shows, seriously and critically studying the foundational texts of their religion in order to challenge received wisdom. In calling for reform of India's Muslim Personal Law, they prefer the authority of the Qur'an rather than either the Indian Constitution or the 'human rights' discourse which guides Indian secular feminists' campaigns for women's rights. We are then once more pointed towards the multi-vocal and complex nature of Islamic debate.

Finally, we turn to discuss this volume in the context of Mahmood's recent discussion of knee-jerk secularism (secularity), and the ways in which it acts in wider society and among academics alike as 
a disciplining mechanism prescribing the limits of 'religion', the preferred aesthetics of religiosity and, indeed, the very existence of a stand-alone category cordoned off as 'the religious' (Mahmood 2006). Academic secularism insists upon a narrow understanding of 'proper religion' or 'religion in its proper place' as a privatized and interiorized question of spiritual connection. It is no surprise, then, if academics have shown an approving bias for South Asian mystic sufi styles of devotionalism and an anxiety about reformist and especially Islamist religiosity. Our position here is to urge a more nuanced examination of all forms of reformism and their reception in practice. We would also hope for academic commentators on South Asian Islam to make a reflexive turn which would press them to try to avoid romanticizing an imagined 'local' and to stop framing their understandings (of Islamism in particular) in terms of moral or aesthetic judgement, while also refraining from assuming instrumentalism or pragmatism, rather than allowing for sincerity and giving weight to projects of piety. As Robinson notes about reform (this volume), 'If the drive came from the inner compulsion of Muslims to make their faith live to the best possible effect, it was shaped in constant interaction with the changing material world in which it existed" (p. ??).

\section{References}

Ahmad, I. \& H. Reilfeld (eds.) 2004. Lived Islam in South Asia: Adaption, Accommodation and Conflict. Oxford University Press, Delhi.

Ahmad, I. (ed.) 1981. Ritual and Religion among Muslims in India. Manohar, Delhi.

Ansari, M. T. 2005. 'Refiguring the Fanatic: Malabar 1836-1922'. In S. Mayaram, M. S. S. Pandian \& A. Skaria (eds.) Subaltern Studies XII. Permanent Black, New Delhi, pp. 36-77.

Asad, T. 1986. The Idea of an Anthropology of Islam. Georgetown University Center for Contemporary Arab Studies, Washington.

Assayag, J. 2004. 'Can Hindus and Muslims Coexist?' In I. Ahmad \& H. Reilfeld (eds.) Lived Islam in South Asia: Adaption, Accommodation and Conflict, Oxford University Press, Delhi, pp. $4^{\mathrm{O}}-5^{8}$.

Bayly, S. 1992. Saints, Goddesses and Kings: Muslims and Christians in South Indian Society I 700- I 900. Cambridge University Press, Cambridge.

Beatty, A. 1996. 'Adam and Eve and Visnu: Syncretism in the Javanese Slametan'. Journal of the Royal Anthropological Institute 2, 2: 271-288.

Blank, J. 2001. Mullahs on the Mainframe: Islam and Modernity among the Daudi Bohras. University of Chicago Press, Chicago, IL.

Bowen, J. R. 1989. 'Salat in Indonesia: The Social Meanings of an Islamic Ritual'. Man (ns) 24, 4: 6oo-619.

Brenner, S. 1996. 'Reconstructing Self and Society: Javanese Muslim Women and 'the Veil'. American Ethnologist 23, 4: 673-697.

Das, V. 1984. 'For a Folk-Theology and Theological Anthropology of Islam'. Contributions to Indian Sociology (ns) 18, 2: 293-300.

Deeb, L. 20o6. An Enchanted Modern: Gender and Public Piety in Shi'i Lebanon. Princeton University Press, Princeton, NJ. 
Devji, F. 2005. Landscapes of the Jihad: Militancy, Morality, Modernity. Hurst \& Co., London.

Eickelman, D. F. \& A. Salvatore (eds.) 2004. Public Islam and the Common Good. Brill, Leiden.

Eickelman, D. F. \& J. Piscatori 1996. Muslim Politics. Princeton University Press, Princeton, NJ.

Ewing, K. 1997. Arguing Sainthood: Modernity, Psychoanalysis and Islam. Duke University Press, Durham.

Fuller, C. J. 1992. The Camphor Flame. Princeton University Press, Princeton, NJ.

Gaborieu, M. 1989. 'A Nineteenth-Century Indian 'Wahhabi' Tract Against the Cult of Muslim Saints: Al Balag al Mubin’. In C. Troll (ed.) Muslim Shrines in India. Oxford University Press, Delhi, pp. 198-239.

Gardner, K. 1985. 'Mullahs, Migrants and Miracles: Travel and Transformation in Rural Bangladesh'. Contributions to Indian Sociology (ns) 27, 2: $213-235$.

Geertz, C. 1960. The Religion of Java. University of Chicago Press, Chicago, IL.

Giddens 1999. Runaway World: How Globalisation is Reshaping our Lives. Routledge, London.

Green, N. 2005. 'Mystical Missionaries in the Hyderabad State: Mu'in Allah Shah and his Sufi Reform Movement'. The Indian Economic and Social History Review 42, 2: $187-212$.

Hansen, T. B. 1999. Wages of Violence: Naming and Identity in Postcolonial Bombay. Princeton University Press, Princeton, NJ.

Hansen, T. B. 2007. 'The India that does not Shine'. ISIM Review 19: $5^{0-5} 5^{1 .}$

Hefner, R. W. 1985. Hindu Javanese: Tengger Tradition and Islam. Princeton University Press, Princeton, NJ.

Henkel, H. 2007. 'The location of Islam: Inhabiting Istanbul in a Muslim Way'. American Ethnologist 32, 1: 57-70.

Hermansen, M. 2000. 'Fakirs, Wahhabis and Others: Reciprocal Classifications and the Transformation of Intellectual Categories'. In J. Malik (ed.) Perspectives of Mutual Encounters in South Asian History, I760-I86o. Brill, Leiden pp. 23-48.

Hirschkind, C. 2006. The Ethical Soundscape: Cassette Sermons and Islamic Counterpublics. Columbia University Press, New York.

Houtman, G. 2006. 'Double or Quits'. Anthropology Today 22, 6: 1-3.

Howell, J. 2001. 'Sufism and the Indonesian Islamic Revival'. Journal of Asian Studies 6o, 3: 701-729.

Keenan, J. 2006. 'Conspiracy Theories and 'Terrorists': How the 'War on Terror' is Placing New Responsibilities on Anthropology'. Anthropology Today 22, 6: 4-9.

Keenan, J. 2007. 'My Country Right or Wrong'. Anthropology Today 23, 1: 2627.

Kresse, K. 2007. Philosophising in Mombasa: Knowledge, Islam and Intellectual Practice on the Swahili Coast. Edinburgh University Press, Edinburgh.

Mahmood, S. 2004. Politics of Piety: The Islamic Revival and the Feminist Subject. Princeton University Press, Princeton, NJ.

Mahmood, S. 2006. 'Secularism, Hermeneutics, and Empire: The Politics of Islamic Reformation'. Public Culture 18, 2: 323-347.

Makris, G. P. 2007. Islam in the Middle East: A living Tradition. Blackwell, Oxford.

Mamdani, M. 2004. Good Muslim, Bad Muslim: America, the Cold War, and the Roots of Terror. Pantheon, New York.

Manger, L. 1998. Local Islam in Global Contexts. Curzon, London

Marsden, M. 2005. Living Islam: Muslim Religious Experience in Pakistan's North-West Frontier. Cambridge University Press, Cambridge.

Mayaram, S. 1997. Resisting Regimes: Myth, Memory and the Shaping of a Muslim Identity. Oxford University Press, Delhi. 
Metcalf, B. 1982. Islamic Revival in British India. University of California Press, Berkeley, CA.

Miller, R. E. 1992 (1976). Mappila Muslims of Kerala: a Study in Islamic Trends. Orient Longman, Madras.

Minault, G. 1984. 'Some Reflections on Islamic Revivalism vs. Assimilation among Muslims in India'. Contributions to Indian sociology (ns) 18, 2: 301-305.

Minault, G. 1998. Secluded Scholars: Women's Education and Muslim Social Reform in Colonial India. Oxford University Press, Delhi.

Otayek, R. \& B. Soares. 2007. 'Introduction: Islam and Muslim Politics in Africa'. In Soares, B. \& R. Otayek (eds.) Islam and Muslim Politics in Africa. Palgrave-Macmillan, Basingstoke.

Robinson, F. 1993. Separatism among Indian Muslims: the Politics of the United Provinces Muslims I 860-1923. Oxford University Press, Delhi.

Robinson, F. 1983. 'Islam and Muslim Society in South Asia'. Contributions to Indian Sociology (ns), 1 7, 2: $185^{-203}$.

Robinson, F. 1986. 'Islam and Muslim Society in South Asia: a Reply to Das and Minault'. Contributions to Indian Sociology (ns), 20, 1: 97-104.

Robinson, F. 2001. The 'Ulama of Farangi Mahal and Islamic Culture in South Asia. Permanent Black, Delhi.

Roy, A. 2005. 'Thinking over 'Popular Islam' in South Asia: Search for a Paradigm'. In M. Hasan \& A. Roy (eds.) Living Together Separately: Cultural India in History and Politics. Oxford University Press, Delhi, pp. 29-61.

Sanyal, U. 1996. Devotional Islam and Politics in British India: Ahmed Riza Khan and his Movement, I 870-1920. Oxford University Press, Delhi.

Sikand, Y. 2002. The Origins and Development of the Tablighi-Jama'at (I92O-200o). Orient Longman, New Delhi.

Simpson, E. 2006. Muslim Society and the Western Indian Ocean: The Seafarers of Kachchh. Routledge, London.

Soares, B. 2005. Islam and the Prayer Economy: History and Authority in a Malian Town. Edinburgh University Press, Edinburgh.

Stewart, C. 1991. Demons and the Devil: Moral Imagination in Modern Greek Culture. Princeton University Press, Princeton, NJ.

Troll, C. W. (ed.) 1989. Muslim Shrines in India. Oxford University Press, Delhi.

Troll, C. W. 1978. Sayyid Ahmad Khan: a Reinterpretation of Muslim Theology. Vikas, New Delhi.

Van Der Veer, P. 1992. 'Playing or Praying: A Sufi Saint's Day in Surat'. The Journal of Asian Studies 51, 3: 545-564.

Van Der Veer, P. 1994. Religious Nationalism: Hindus and Muslims in India. University of California Press, Berkeley, CA.

Verkaaik, O. 2004. Migrants and Militants: Fun and Urban Violence in Pakistan. Princeton University Press, Princeton, NJ.

Waseem, M. (ed. \& trans.) 2003. On Becoming an Indian Muslim: French Essays on Aspects of Syncretism. Oxford University Press, Delhi.

Werbner, P. 2003. Pilgrims of Love: The Anthropology of a Global Sufi Cult. Indiana University Press, Bloomington, IN.

Werbner, P. \& H. Basu (eds.) 1998. Embodying Charisma: Modernity, Locality and the Performance of Emotion in Sufi Cults. Routledge, London.

Woodward, M. 1988. 'The Slametan: Textual Knowledge and Ritual Performance in Central Javanese Islam'. History of Religions 28, 1: 54-89.

Zaman, M. Q. 1999. 'Religious Education and the Rhetoric of Reform: the Madrasa in British India and Pakistan'. Comparative Studies in Society and History, 41, 2: 294-323.

Zaman, M. Q. 2002. The Ulama in Contemporary Islam: Custodians of Change. Princeton University Press, Princeton, NJ. 